\title{
SUSTAINABLE CORPORATE GOVERNANCE - THE PURPOSE OF THE COMPANY
}

\author{
Bistra Boeva ${ }^{1}$ \\ e-mail: bboeva2@unwe.bg
}

\begin{abstract}
The objective of this paper is to explore the latest trends in sustainable corporate governance with a focus on the purpose of the company. Referring to her previous research projects and publications, the author aims to build on the preceding findings and research results. The objective of the paper is to give an answer to whether company purpose (the new mantra) is a totally new concept within the framework of corporate governance or, in other words, whether the business community has changed completely and whether a new business model has been developed by academia, consultants and business leaders.

To answer these questions the author has initiated a literature survey and web mining to get a fresh perspective from the corporate practices in the EU and US economies. Experts'views and judgement are discussed in order to obtain information about the agenda and priorities of listed Bulgarian companies.

The paper is structured as follows: overview of sustainable corporate governance (introduction); survey on the academic views on the purpose of the company (part one); investigation of the business views on the purpose (part two) and the corporate governance agenda - shareholders' perspective on the purpose studies (part four) and conclusions and suggestions for future research.
\end{abstract}

Key words: corporate governance, purpose; shared value, sustainability/sustainable development, stakeholders

JEL: G34, L21, P19

\section{Introduction}

According to the conceptual framework of this paper and the established definitions, corporate governance "involves a set of relationships between a company's management, its board and shareholders. Corporate governance also provides the structure through which the objectives of the company are set, and the means of attaining those objectives and monitoring performance are determined" (G20/OECD, 2015, p. 9). The need to strike a balance between the interests of the owners, corporate boards and stakeholders in the process of creating value

1 Prof., D.Sc. (econ), Department of International Economic Relations and Business, University of National and World Economy 
in a context of dynamic, risky and unpredictable environment is fundamental to modern, as well to sustainable corporate governance. On the one hand is the internal structure - shareholders, and their representatives (corporate boards) and certain stakeholders (employees, trade unions), on the other - the external architecture: stakeholders (suppliers, global supply chains, consumers, various grassroots organizations). The dynamic and unpredictable environment has impacted both structures. The usage of the word "conquer" is justified by the recent trends and their impact on these structures. The battle against climate change and COVID-19, the battle for the human rights protection and decent work conditions determines the new reality - the transition from the well-known shareholders' value to the purpose of the company, the transition from the traditional short-term shareholders' engagement to the long-term shareholders' engagement, the transition from compliance with the stakeholders' rights to stakeholders' engagement. Many studies have examined the transformation of shareholders' behavior from profit decision-making entities and individuals to responsible investors. Research from various countries aims to investigate the changing mindset of the corporate boards with regard to the sustainable development. Gradually the driving forces behind sustainable corporate governance have been identified - investors, stakeholders, consumers. Within the EU, as well within the USA and other economies, the lawmakers and regulators are crafting a legal framework (EU Taxonomy Regulation, Due Diligence Directive, etc.) for a sustainable corporate governance. It is an ongoing process and new phenomena continue to impact the corporate governance structures. With this in mind, in the next part of the study certain observations on a topical issue - the purpose of the company - are discussed.

\section{The shift from profit shareholder value to purpose and value creation}

At the end of the second decade of the $21^{\text {st }}$ century and the beginning of the third, discussions (mostly online) are focused on the topic of "the purpose of the company" (Coffee, 2020). Although the notion of corporate purpose is not a novel idea, it has reentered into public discourse in recent years (Ernst \& Young Global, 2020) - academics, influential non-profit organizations and practitioners are competing in articulating the need for the transformation of business - "business as usual" - with regard to climate change, increasing inequality within societies and countries. Economic studies, legal research and management studies look for evidence to justify this new agenda for corporate governance, as well for management. 


\section{Disruptive academic research on the new corporate governance trends}

The term "disruptive" is associated with developments in the domain of science, applied research and technology and the Industrial Revolution 4.0. A disruptive technology replaces a traditional practice with a new unknown technological decision. The mantra "disruptive" is reserved for the STEM (Science, Technology, Engineering, Mathematics) area. In this part of the paper the objective is to justify the label "disruptive" for certain academic research and concepts in economics and corporate governance. One of these research areas is focused on the British Academy study on the new corporation including Colin Mayer's statement on the purpose of the company ${ }^{2}$. In the document on the Principles of Purposeful Business, British scholars declare, "the purpose of business is to solve the problems of people and planet profitably, and not profit from causing problems (British Academy, 2018, p. 8) it should then be a product of a corporation's purpose, but not the purpose of the corporation"3. The eight principles for a purposeful business set up the framework for the implementation of this new direction for business. The framework encompasses legal norms, regulation requirements and guidance, shareholders' commitment to supporting the purpose, stakeholders' engagement via relevant corporate governance structures, investors' priorities and respective metrics for company performance.

A careful reading and decoding of the principles reveals that profit, returns of investment are not excluded from the new concept about the purpose. The focus is on long-term investments, including investments by companies in societies and natural assets, and on the "fundamental shareholders" right to derive financial benefit". "In sum, the eight principles of law, regulation, ownership, governance, measurement, performance, finance, and investment can therefore be as consistently and coherently aligned with problem solving purpose as with shareholder primacy" (Mayer, 2020). Both the Principles of the purposeful business and professor Mayer's publications (Mayer, 2020) are a response to the problems related to global financial crises, as well as to environmental, social and governance issues. One has to keep in mind that the theory about the purposeful business aims to establish not only a new model for company behavior but also a new model for the market economy. Publications on purpose have to be understood in the context of the AngloSaxon model of corporate governance, as well as in the context of the British concepts of the rights and obligations of the investors (FRC, 2010, Steward-

${ }^{2}$ In 2018 British Academy (British Academy for Humanity and Social Sciences) launched a project about the future of the company.

3 The research, the results and conclusion embedded views of more than 350 people in UK. As the information states the principles are response to the issue that challenge the business in the $21^{\text {st }}$ century. 
ship Code). Professor Mayer examines certain best international practices in EU companies and in companies from other countries as well. It is a British reading of the new trajectory of the company. This paper aims to study this new disruptive concept about the rationale of business activity and to examine its impact on business. It is true that the definition about the purpose and the effort to shift the paradigm from well-known priorities, such as profit and shareholders' value, exposes a totally new approach to the various reasons for doing business. Profit and shareholders' value are replaced by the solution of societal and climate issues by the company. The concept is an answer to the problems of businesses and the risks to which they are exposed. It does not reject the economic rationale of doing business at all. The concept is about responsible business aiming to balance the interests of the owners and the interests of the stakeholders in the environment of Industrial revolution 4.0, the new generation as an active work force, investors, consumers and grass roots - Millennials. Actually, this disruptive proposal is a well-crafted model for the balance of economic, environmental and societal objectives that the business has to follow.

Are there similar views to the British concept?

\section{The purpose - the Norwegian view regarding the purpose}

Another representative of academia that proposes the concept of purpose is the Norwegian law professor B. Sjafjeill. According to professor B. Sjafjeill (2018), the purpose of the undertaking is to create sustainable value within planetary boundaries, balancing the interests of investors and other involved and affected parties. How do we understand the above definition? The focus is on the sustainable value. The author replicates the well-known concept about shared value (Porter, Kramer, 2011) and the necessity to balance the interests of the key actors in the market economy - the owners/investors and stakeholders ${ }^{4}$. A new component of the above definition is the component of planetary boundaries ${ }^{5}$. The

${ }^{4}$ Prof. B. Sjafjeill is among the leaders of the EC funded project Sustainable Market Actors Across Trade borders (SMART).

5 The concept about the planet boundaries is created by the Stockholm resilience centre in 2009. According to the authors of the concept, the life of mankind on the planet at present and in the future is determined by seven processes that regulate the stability and resilience of the earth's system. The scientists proposed quantitative planetary boundaries within which humanity can continue to develop and thrive for generations to come. Crossing these boundaries increases the risk of generating large-scale abrupt or irreversible environmental changes. It is worth noting that these processes are the following: climate change, stratospheric ozone depletion; land system change; ocean acidification; biochemical flows (nitrogen and phosphor flows to the ocean); freshwater use; biosphere integrity; atmospheric aerosol loading; chemical pollution and novel entities. This scientific approach, including respective quantitative evaluation of the "boundaries", corresponds to Sustainable 
concept of "planetary boundaries" pertains to the key elements of the physical environment (climate change, pollution etc.) that determine the conditions for the life of mankind - present and future generations on our planet. Changes (increase) in the levels (boundaries) of these components could have a negative impact on humanity - both at present and in the future. To put it another way, business as usual has to shift to business on alert for the changes in the planetary boundaries. Going back to previous academic studies and publications of international organizations (Brundtland, 1987), one could draw the conclusion that analogous factors have been examined in the same context - the conditions of life on the planet. The concept of professor Sjafjell focuses on the environment. Although Norwegian companies are known for their respect for stakeholders (see Norwegian Sovereign wealth fund - Todorov, 2021), the stakeholders are excluded from the concept of the purpose. The legal background of the author determines the proposal for changes in the legal norms about the corporation and its purpose.

\section{The M. Porter and M. Kramer concept about shared value}

The idea about the new direction of companies, corporate governance and management is associated with the concept about shared value. As a quick response to the global financial crisis (2007), this concept, introduced by professor M. Porter and professor M. Kramer (Porter, Kramer, 2011), attempts to propose new priorities for the company. This means creating traditional economic benefits in a way which delivers value for society (social value), reflecting its needs and challenges. The rationale behind this new approach is clearly articulated by the above mentioned authors: "addressing societal harms does not necessarily raise costs for the firms". More to the point, a company could achieve better results when economic players are involved in the resource provisions of its business (the cluster that the company coexists with, wherever it operates). Cluster encompasses education, employees' skills, health, safety, affordable housing, community development, water use, energy use, environmental impact.

\section{The new is the old - Triple Bottom line (TB)}

The observation of the concepts of different schools of thought - economic, legal, management and corporate governance merits a reference to J. Elkington's (1997) concept about TBL. Although a product of an earlier period of capitalism (prior to the global financial crisis 2007), this concept casts light on the

Development Goals 2015; to the six priorities of the Green Deal and to the established and to accepted ESG disclosure and sustainability reporting. 
new approaches to the issues of stakeholders, the environment and social affairs. The business community has to achieve simultaneously positive financial results (profit P), tangible social policy results - meeting the needs of the company's employees (people P) and being active in environmental protection (planet P). At present the most popular TBL modification is the ESG formula (Environment, Social, Governance), which is associated with sustainability/sustainable development and sustainable corporate governance ${ }^{6}$.

\section{Preliminary conclusions}

Certain questions arise among which are: what is the essence of purpose and do the above standpoints present different views or disruptive solutions about the business model? The answer is not so easy and the simplification does not serve the objectives of this study. It is worth examining the origins of the above views. The authors utilize knowledge from the economics (Mayer), law (Sjafjell) and management (Porter, Kramer). In his publication of 2018, Mayer examines various issues - ownership, corporate governance and defines his understanding about the novelty of the directions of business. In terms of environment his views are related to the environmental (natural) and social capital. Professor B. Sjafjell focuses on value and pictures the environment from the perspective of science. This scientific approach, including respective quantitative evaluation of the "boundaries", corresponds to Sustainable Development Goals 2015; to the six priorities of the Green Deal and to the established and accepted ESG disclosure and sustainability reporting. Professor M. Porter and M. Kramer develop their cluster according to the "planet boundaries" from a slightly different perspective. ${ }^{7}$ By examining the above view through the lens of the company's direction and its relationship with the environment, it is not so difficult to find a difference. The Norwegian concept excludes the stakeholders.

The comparison of the views about the new direction of the company makes it possible to draw certain conclusions:

- With regard to the global financial crisis (2007) academics have developed new ideas about the directions of the company, including the listed company. Certain problems - inequality; social imbalances and underestimation of the environmental factors by the business community have given rise to a new area of research. Academic efforts are aligned with certain regulation activities of the governments in market economies (EU, USA etc.).

${ }^{6}$ ESG or ESG disclosure is used in the corporate world and various standards and regulations (EU level, member states level, etc.).

7 The cluster that the company coexists with includes: environmental impact water use, energy use, community development, affordable housing, safety, health, employee skills, education. 
- Although the abovementioned views do not consider profit for the strategic directions of the company, profit is the core component of the purpose. The attempt to use other words and avoid the articulation of the word profit does not mean that business is a non-profit endeavour. At present it is difficult to support the view that companies have to be managed as non-profit organizations (Mayer, 2018).

- The rationale behind the views about the purpose and shared value is the reaction to the urgent need to save the planet and to mitigate social issues. The shift from traditional views about profit, shareholder value to the disruptive views about the main driver for investors, corporate boards and managers is a trend that deserves to be examined from the viewpoint of other researchers and practitioners.

\section{The purpose in the focus of academia, consultants, NGOs and the business community}

\section{Academia on the subject of purpose}

In the last couple of years $(2020$ - 2021), as mentioned above, a large number of online discussions are trying to decode, accept or reject professor Mayer's concept about the purpose ${ }^{8}$. The European Corporate Governance Institute (a pool of prestigious publications on corporate governance) has attracted academic representatives from Europe (older EU member states and only a handful from countries with formerly planned economies), Australia, Japan and the USA in these discussions. Positions differ. One conclusion could be drawn: there is a lack of agreed positions on what the purpose of the company is. Agreement was achieved on the challenges that the business community has to face.

Professor Coffee (2021) observes the above discussions and concludes that the new paradigm of the purpose is about the primacy of the stakeholder, as opposed to the notion of shareholder value that has been popular for years. His view about who bears responsibility for developing the company purpose is clear - these are corporate boards. The role of shareholders is not excluded in this process - the purpose has to be integrated in the company bylaws and it is at the owners' discretion to determine the ESG driven agenda.

The British concept on purpose and certain comments on the stakeholders, including seeing the stakeholders as a hindrance to the company (Mayer, 2018, 2020), are criticized by certain scholars (Nevins, 2019). German scholars, from the perspective of the established co-determination practice and the theory of

\footnotetext{
8 A study conducted by EY and Oxford University Said Business School found that public conversation about purpose increased fivefold between 1995 and 2014.
} 
productive coalition ${ }^{9}$, see the British concept as a well-known practice that German businesses have stuck to since the 1970s.

\section{Business views on the purpose}

Among the arguments about the practicality of the purpose concept is the Business Roundtable case. In 2019 around 180 CEOs of US companies signed their manifesto on the Purpose of the company, which states "the purpose of the corporation is to promote an economy that serves every American" (Business Roundtable, 2019 $)^{10}$. Although there is no definition about the purpose, the document clarifies the engagement of big US multinationals (Apple, GM, Amazon, Bank of America, JP Morgan) to meet the needs and solve the problems of their stakeholders - suppliers, consumers, and communities and to deliver value to the shareholders. The CEOs do not reject the capitalist ethos. There is a shift from the business as usual to business with respect to all stakeholders. ${ }^{11}$ It is my opinion that the review of the websites of the above-mentioned companies does not provide arguments that the companies as a system/business and legal entity apply the concept of purpose.

Searching for more convincing evidence, I came across a different view about purpose - purpose as a personal engagement of the CEOs, Board Chairs (Gast et al., 2019; Nevins, 2020) and is linked to the culture and strategy of the organization. According to the McKinsey study, the purpose statements of the companies are generic. Another well-known consultant, Ernst \& Young (2020), articulates the same understanding about the purpose: "Exploring the subject in some depth, we have come to define corporate purpose as an aspirational reason for being that is grounded in humanity and inspires a call to action. But this is also starting to shift - to a broad, human-centered, socially-engaged conception of purpose that seeks to create value for multiple stakeholders. While many organizations claim to have a purpose, we have started to define this new, deeper articulation of intent as Purpose (with a capital P)". The E\&Y analysis on the purpose of a group of companies reveals that for most of them there is a significant gap between the

9 The author of the article refers to the discussions about the British concept of purpose, organized by the European Corporate Governance Institute in 2020 and 2021.

10 The Business Roundtable is a business association, that unifies the CEOs of US companies. According to the website of this association its members employ 15 million people.

11 "What I believe is that we have everything we need to deliver a more sustainable and equitable future - talent, technology, manufacturing footprint and scale, industry leading customer loyalty, strong dealers and great partners and suppliers. Integrating all of these elements is what we do best, and we are committed to bringing our speed and sense of urgency to help create a more sustainable future for all." Mary T. Barra, Chairman and Chief Executive Officer of General Motors. 
belief that purpose should be integrated into an organization and their ability to actually do so.

The conclusions that could be drawn from the above surveys are to a certain degree in line with the main thesis of this paper's author: There is a clear trend for a shift from the traditional only profit-based business model. Companies are navigating through the lack of trust of the younger generation with regard to business, climate change, societal inequality, digitalization (E\&Y) and unpredictable future.

The changes to the traditional business trajectories is a slow process of balancing economic results and the needs of society. It is the reason for the generic statements about and for different approaches to the crafting of the purpose for the sustainable business and sustainable corporate governance.

\section{Academia, business and stakeholders on purpose}

The survey on various concepts and studies on purpose ends with one of the most influential documents on the subject: "Davos Manifesto 2020: The Universal Purpose of a Company in the Fourth Industrial Revolution". The purpose has "to engage all its stakeholders in shared and sustained value creation". With leadership provided by the WEF founder professor Schwab and representatives of the business community, academia and NGOs, this Manifesto determines the benchmarks that the companies have to align with. The statement answers an important question for the company about how to "understand and harmonize the divergent interests of all stakeholders through a shared commitment to policies and decisions that strengthen the long-term prosperity of a company". With a focus on environmental and social issues, the Davos Manifesto sheds light on one of the mega directions for every business in the $21^{\text {st }}$ century - how to function with regard to the Industrial Revolution 4.0. With WEF priorities ${ }^{12}$ in mind, it is worth noting that the Davos Manifesto on purpose is based on the conclusions of various studies on ESG issues and economic rationale for business existence. Although certain examples will be offered in the next paragraph, the Davos view on one of the components of purpose - shared and sustained value creation - is declared as a purpose of one of the multinationals, namely of Nestle.

12 The studies on competitiveness, job reset; the impact of AI on human beings, as well inequality, climate changes and the latest about COVID-19. 


\section{Regarding the evidence ${ }^{13}$}

Although in the previous parts I reflect on the concepts, as well on certain statements of the practitioners, academic research requires a down-to-earth approach to the topics in question. In this part of the paper the objective is to compare conceptual views on the purpose with the business reality across the world. With regard to the British and Norwegian concepts, I have studied corporate governance codes. The concept about the purpose of the company is not widespread in Europe. Being a British concept, it is supported by the business community in the UK. Among the principles of UK Corporate Governance is the principle about the Board leadership and its engagement to establish the purpose and value of the company (Financial reporting council, 2018). In my view, it should be highlighted that certain examination (web mining) of the websites of UK companies did not provide a clear understanding about how businesses have interpreted the new concept. On the other hand, it should be pointed out that British companies undertake measures to tackle climate change, to comply with UN Guidelines for business and human rights. In other cases, such as Unilever caring for environment and the community is a tradition rooted in a history going back decades. It is noteworthy to refer to the statement of the previous Unilever CEO - P. Polman about the purpose: "Thoughtful and well-argued, Mayer has done the cause of enlightened capitalism great service" (P. Polman).

A quick review of the Norwegian code of Corporate Governance revealed a lack of purpose, given that the focus is on value creation. The Swiss multinational Nestle shifts from shared value (Porter, Kramer, 2011) to Creating Shared Value (CSV). This is how we ensure a long-term positive impact for all our stakeholders. Our work is guided by our three global ambitions: to support children, develop communities and preserve the planet for the future.

And finally, an expert's opinion is outlined to reflect on shareholders' behavior with regard to the challenges the business is exposed to. Two samples and expert conclusions were examined: a sample of US-listed companies and Bulgarianlisted companies. The litmus test was the shareholders' suggestions for the Annual Shareholders General Meeting (AGM) agenda. According to information by the influential US NGO Ceres that is a trendsetter for sustainable corporate governance, some $98 \%$ of US-listed companies reported that the shareholders' proposal that the AGM agenda (2021) includes the topic of climate change. An expert opinion communicates that there is not a single Bulgarian-listed company with a proposal on the subject of climate change for the AMG agenda. ${ }^{14}$

13 A pure academic research that employed quantitative research methods includes the robust test to verify the research results. In this article the robust test has a different role: it is to verify the concepts with certain examples from the business practice.

14 The information about Bulgaria companies includes data for the first sixth months of 2021. 


\section{Conclusion}

This paper is a follow-up of my previous research and publications on sustainable corporate governance, as well my work on International Finance Corporation projects about sustainable corporate governance and ESG disclosure. The topic has not been explored by Bulgarian researchers. The purpose is not on the agenda on Bulgarian listed companies and public entities (SOEs). Although Bulgarian business is a step ahead in terms of crises in the last three decades we have survived the transition from a planned to a market economy, the global financial crisis and COVID-19, the new understanding about the rationale for doing business/purpose is not shared by our business leaders. Corporate social responsibility is a mantra one could find on company websites.

My observation on the concepts about purpose has revealed a lack of a clear and pragmatic view. In this regard the above conclusion is supported by the final comments of professor C. Mayer (2020). He assures us that "to recognize the importance of purpose is only the beginning. It raises questions about what purpose means, how it is implemented, and how it gains legitimacy and credibility" (Mayer, 2020, p. 16).

What is most important is that there is a common understanding that work should be carried out on all company levels so that both shareholders and stakeholders matter and the cliché "license to operate" will transform into more visible horizons for the business - "Planet People - Prosperity".

\section{References}

Barker, R. (2020). Accounting for natural capital, in Mayer, C. and Roche, B. (Eds), Putting Purpose into Practice: The Economics of Mutuality. Oxford: Oxford University Press.

Boeva, B. (2019). Capital, melting glaciers and $2^{\circ} \mathrm{C}$, publishing house Iztok Zapad, Sofia.

British Academy of Science. (2018). Principles for Purposeful Business. How to deliver the framework for the Future of the Corporation. An agenda for business in the 2020s and beyond.

Brundtland, G. (1987). Report of the World Commission on the Environment and Development: Our Common future. Transmitted to the General Assembly as an Annex to document A/42/427 - Development and International Co-operation: Environment, available at: http://www.ask-force.org/web/Sustainability/ Brundtland-Our-Common-Future-1987-2008.pdf

Business Roundtable. (2019). Statement on the purpose of the company, available at: https://s3.amazonaws.com/brt.org/BRT-StatementonthePurposeofaCorpor ationJuly2021.pdf 
Coffee, J. (2021). Purposeful Business, retrieved from www.ethicalboardroom. $\mathrm{com} /$

Elkington, J. (1997). Cannibals with forks: the triple bottom line of 21st century business". Capstone.

Ernst \& Young Global. (2020). Why business must harness the power of purpose, available at: https://www.ey.com/en_gl/purpose/why-business-must-harnessthe-power-of-purpose

Financial reporting council. (2010, 2018). UK Corporate Governance Code, available at: https://www.frc.org.uk/getattachment/88bd8c45-50ea-484195b0-d2f4f48069a2/2018-UK-Corporate-Governance-Code-FINAL.PDF G20/OECD. (2015). Principles of Corporate Governance, OECD, P.

Gast, A., Illanes, P., Probst, N., Schaninger, B., Simpson, B. (2020). Purpose: Shifting from why to how, McKinsey Quarterly, available at: https://www. mckinsey.com/business-functions/organization/our-insights/purpose-shiftingfrom-why-to-how

Mayer, C. (2020). The Future of the Corporation and the Economics of Purpose, Finance Working Paper 710/2020, ECGI.

Mayer, C. (2018). Prosperity, better business makes the greater good, Oxford University Press.

Nevins, M. (2019). What Is The Purpose Of A Company?, Forbes [online], available at: https://www.forbes.com/sites/hillennevins/2019/08/28/what-isthe-purpose-of-a-company/?sh=467402546d89

Porter, M., Kramer, M. (2011). The big idea creating share values, HBR, JanuaryFebruary.

Sjafjell, B. (2019). Sustainable Market actors for responsible Trade, SMART project 2019.

Sjåfjell, B. (2018). Redefining corporation for a sustainable new economy, Journal of Law and Society, vol.45, Issue 1.

Schwab, K. (2020). Davos Manifesto 2020: The Universal Purpose of a Company in the Fourth Industrial Revolution. World Economic Forum, available at: https://www.weforum.org/agenda/2019/12/davos-manifesto-2020-theuniversal-purpose-of-a-company-in-the-fourth-industrial-revolution/

Todorov, E. (2021). Sovereign wealth funds - a factor in contemporary international relations, $\mathrm{PhD}$ Thesis, UNWE.

World Economic Forum. (2020). Measuring Stakeholders capitalism: Towards Common Metrics and Consistent Reporting of Sustainable Value Creation, White paper 2020. 